\title{
Nutritional evaluation of products prepared from fresh beans
}

\author{
Mamta Rani* and Darshan Punia \\ Department of Foods and Nutrition, CCS Haryana Agricultural University, Hisar- 125004 (Haryana), INDIA \\ *Corresponding author. E-mail: mamtarajoria12@gmail.com
}

Received: October 28, 2016; Revised received: May 1, 2017; Accepted: September 18, 2017

\begin{abstract}
The objective of this study was to determine the nutritional composition of products prepared from fresh beans. Four types of fresh beans powder viz. cluster bean (Cyamposis tetragonaloba), cowpea bean (Vigna unguiculata), french bean ( Phaseolus vulgaris) and sem bean (Dolichhos lablab) were used for dry vegetable preparation. Moisture content of beans vegetable prepared using fresh beans ranged from 76.49 to 82.25 per cent. The cowpea bean vegetable had the highest $(17.19 \%)$ and sem bean vegetable had the lowest $(12.67 \%)$ amount of crude protein. Crude fiber content was found to be highest in cowpea bean vegetable $(6.69 \%)$ followed by cluster bean vegetable $(6.60 \%)$, french bean vegetable $(6.41 \%)$ and sem bean vegetable $(5.54 \%)$. Among the four types of beans vegetables, total, insoluble and soluble dietary fiber content was found to be highest in cluster bean vegetable and the lowest in sem bean vegetable. Sem bean vegetable contained the maximum $(135.81 \mathrm{mg} / 100 \mathrm{~g}$ and 251.46 $\mathrm{mg} / 100 \mathrm{~g}$ ) amount of calcium and phosphorus while french bean vegetable contained the minimum (51.03 $\mathrm{mg} / 100 \mathrm{gand} 243.55 \mathrm{mg} / 100 \mathrm{~g}$ ) amount. Iron content was significantly $(\mathrm{P} \leq 0.05)$ higher in cluster bean vegetable and cowpea bean vegetable as compared to french bean vegetable and sem bean vegetable. Cowpea bean vegetable contained the maximum $(101.51 \mathrm{mg} / 100 \mathrm{~g})$ while sem bean contained minimum $(61.19 \mathrm{mg} / 100 \mathrm{~g})$ amount of magnesium. It was observed that all the four types of beans vegetable differed significantly $(p \leq 0.05)$ among themselves for their potassium content. Earlier studies were conducted on raw seeds or pods of beans but information on cooked beans was scanty. This study explains about the effect of cooking on different nutritional components of fresh beans pods.
\end{abstract}

Keywords: Beans, Crude protein, Dietary fiber, Iron, Potassium

\section{INTRODUCTION}

Among the vegetables, the Fabaceae constitute a broad and very large botanical family, consisting of more than 751 genera and over 19,000 species. Beans, the major constituents of this family, are utilized both for fresh green pods as vegetable and dry seeds as pulse (Christenhunz and Byng, 2016). It is essential from nutritional and marketing view point that the growing pods are harvested at a right stage to optimize the gains with respect to their yield and quality (Saxena et al., 2010). The vitamins A and C present in green beans are an excellent antioxidant that reduces the amount of free radicals in the body and prevent the building up of plaque in arteries and veins. The green pods are rich source of proteins, minerals and vitamins (Punia et al., 2008). Beans are often the main source of protein, and a significant source of minerals for lowincome population (Laparra et al., 2009). Fresh raw green beans are the major vegetable types that consumers purchases for consumption, while processed vegetables in the dried, frozen and canned forms are also available. Frozen beans retain the constituents of the raw material to a higher degree than canned products (Kmiecik et al., 2007). Steamed or fried beans are increasingly being used in salads. There is little attention paid to its nutritive value (Deol and Bains, 2010). Cooking is known to alter sensory attributes and nutritional quality while the consumption of vegetables depends largely on their sensory appeal rather than their nutritional quality (Kala and Prakash, 2006). This paper reports the nutritional evaluation of biscuits prepared by incorporating different fresh beans powder.

\section{MATERIALS AND METHODS}

Fresh samples of green beans viz., cluster bean (Cyamposis tetragonaloba), cowpea bean (Vigna unguiculata), french bean (Phaseolus vulgaris) and sem bean (Dolichhos lablab)were cleaned and washed under tap water to remove dirt and dust. The washed beans were spread over filter paper to remove excess water and cut into small pieces. For preparation of dry beans vegetables, fresh beans $(100 \mathrm{~g})$, tomato $(30 \mathrm{~g})$, onion $(30 \mathrm{~g})$, oil $(10 \mathrm{~g})$, salt (to taste), cumin seeds (1g), garlic and ginger paste ( $1 / 2 \mathrm{tsp})$, red chilli powder $(1 / 2$ tsp) and garam masala (1/4 tsp) were used. The mean scores of sensory characteristics were analysed using 9 -point hedonic scale (Ranganna, 1986).

The dry vegetables prepared using fresh beans were evaluated for their nutrient composition. All the four types of vegetables were oven dried to a constant 
weight at $60^{\circ} \mathrm{C}$, ground to a fine powder in an electrical grinder and analyzed for various nutrients. Proximate composition including moisture, protein, fat, ash and crude fiber was determined by standard methods (AOAC, 2000). Total, soluble and insoluble dietary fiber constituents were determined by the enzymatic method given by Furda (1981). Total minerals were determined according to the method of Lindsey and Norwell (1969).

\section{RESULTS AND DISCUSSION}

Beans vegetable prepared using sem bean had significantly $(\mathrm{P} \leq 0.05)$ higher $(82.25 \%)$ moisture content as compared to french bean vegetable $(77.34 \%)$, cowpea bean vegetable $(76.93 \%)$ and cluster bean vegetable. Cowpea bean vegetable contained significantly higher $(17.19 \%)$ amount of crude protein as compared to cluster bean vegetable $(12.93 \%)$, french bean vegetable $(14.29 \%)$ and sem bean vegetable $(12.67 \%)$. The values of protein content found are consistent to those reported by Rachna (2006) in Moringa oleifera products, Chaudhary (2011) in snap peas products and Rani et al. (2013) in pulao containing fresh beans. The vegetable prepared using various fresh green beans showed a very narrow variation in the fat and ash content. The values of fat content of the products obtained in the present study are comparable to the values reported by Rachna (2006) and Chaudhary (2011) in the products prepared using Moringa oleifera and snap peas, respectively. Crude fiber content was found to be highest in cowpea bean vegetable $(6.69 \%)$ followed by cluster bean vegetable $(6.60 \%)$, french bean vegetable $(6.41 \%)$ and sem bean vegetable $(5.54 \%)$. These results are consistent to those reported by Rachna (2006), Bajpai (2011), Chaudhary (2011) and Rani et al., (2014).

It was observed that cluster bean vegetable contained maximum (37.34 \%) amount of total dietary fiber whereas sem bean vegetable the minimum (26.89\%). Cluster bean vegetable had significantly $(\mathrm{P} \leq 0.05)$ higher $(24.52 \%)$ insoluble dietary fiber content compared to cowpea bean vegetable $(19.93 \%)$, french bean vegetable (18.24\%) and sem bean vegetable (17.93\%). Soluble dietary fiber content was similar in cluster bean vegetable $(12.77 \%)$, cowpea bean vegetable $(11.15 \%)$ and french bean vegetable $(11.51 \%)$ but all these three types of vegetable had significantly $(\mathrm{P} \leq 0.05)$ higher soluble dietary fibre as compared to

Table 1. Proximate composition of beans vegetable ( $\mathrm{g} / 100 \mathrm{~g}$ dry weight basis).

\begin{tabular}{lllll}
\hline Type of vegetables & $\begin{array}{l}\text { Moisture } \\
(\mathbf{g} / \mathbf{1 0 0 g})\end{array}$ & $\begin{array}{l}\text { Crude protein } \\
(\mathbf{g} / \mathbf{1 0 0 g})\end{array}$ & Fat (g/100g) & $\begin{array}{l}\text { Crude fiber } \\
(\mathbf{g} / \mathbf{1 0 0 g})\end{array}$ \\
\hline Cluster bean & $76.45 \pm 0.72$ & $12.93 \pm 0.38$ & $13.50 \pm 0.67$ & $6.60 \pm 0.03$ \\
Cowpea bean & $76.93 \pm 0.17$ & $17.19 \pm 0.63$ & $13.33 \pm 0.33$ & $6.69 \pm 0.12$ \\
French bean & $77.34 \pm 0.57$ & $14.29 \pm 0.29$ & $13.50 \pm 0.76$ & $6.41 \pm 0.22$ \\
Sem bean & $82.25 \pm 0.72$ & $12.67 \pm 0.42$ & $13.67 \pm 0.17$ & $5.54 \pm 0.08$ \\
CD $(\mathrm{P} \leq 0.05)$ & 1.96 & 1.49 & $\mathrm{NS}$ & 0.45 \\
\hline
\end{tabular}

Values are mean $\pm \mathrm{SE}$ of three independent determinations

Table 2. Dietary fiber content of fresh beans vegetable ( $\mathrm{mg} / 100 \mathrm{~g}$, dry weight basis).

\begin{tabular}{llll}
\hline Type of vegetables & Total dietary fiber $(\mathbf{g} / \mathbf{1 0 0 g})$ & Insoluble dietary fiber $(\mathbf{g} / \mathbf{1 0 0 g})$ & Soluble dietary fiber $(\mathbf{g} / \mathbf{1 0 0 g})$ \\
\hline Cluster bean & $37.31 \pm 0.49$ & $24.54 \pm 0.51$ & $12.77 \pm 0.62$ \\
Cowpea bean & $31.08 \pm 0.44$ & $19.93 \pm 0.71$ & $11.15 \pm 0.43$ \\
French bean & $29.75 \pm 0.75$ & $18.24 \pm 0.40$ & $11.51 \pm 0.68$ \\
Sem bean & $26.46 \pm 0.44$ & $17.93 \pm 0.10$ & $8.53 \pm 0.11$ \\
$\mathrm{CD}(\mathrm{P} \leq 0.05)$ & 1.81 & 1.60 & 1.68 \\
\hline
\end{tabular}

Values are mean $\pm \mathrm{SE}$ of three independent determinations

Table 3. Mineral content of fresh beans vegetable (mg/100g, dry weight basis).

\begin{tabular}{|c|c|c|c|c|c|c|c|}
\hline $\begin{array}{l}\text { Type of } \\
\text { vegetable }\end{array}$ & $\begin{array}{l}\text { Calcium } \\
(\mathrm{mg} / \mathbf{1 0 0 g})\end{array}$ & $\begin{array}{l}\text { Phosphorous } \\
\text { (mg/100g) }\end{array}$ & $\begin{array}{l}\text { Iron } \\
(\mathrm{mg} / 100 \mathrm{~g})\end{array}$ & $\begin{array}{l}\text { Zinc } \\
(\mathrm{mg} / \mathbf{1 0 0 g})\end{array}$ & $\begin{array}{l}\text { Magnesium } \\
(\mathrm{mg} / \mathbf{1 0 0 g})\end{array}$ & $\begin{array}{l}\text { Manganese } \\
(\mathrm{mg} / \mathbf{1 0 0 g})\end{array}$ & $\begin{array}{l}\text { Potassium } \\
(\mathrm{mg} / 100 \mathrm{~g})\end{array}$ \\
\hline \multirow[t]{2}{*}{ Cluster bean } & $101.88 \pm$ & $248.55 \pm$ & $6.81 \pm$ & $3.87 \pm$ & $93.61 \pm$ & $1.39 \pm$ & $945.84 \pm$ \\
\hline & 2.24 & 0.96 & 0.24 & 0.30 & 0.78 & 0.23 & 0.95 \\
\hline \multirow{2}{*}{$\begin{array}{l}\text { Cowpea } \\
\text { bean }\end{array}$} & $58.38 \pm$ & $246.37 \pm$ & $6.22 \pm$ & $3.18 \pm$ & $101.51 \pm$ & $1.23 \pm$ & $919.41 \pm$ \\
\hline & 0.97 & 0.44 & 0.07 & 0.05 & 1.89 & 0.28 & 1.94 \\
\hline \multirow[t]{2}{*}{ French bean } & $51.03 \pm$ & $243.55 \pm$ & $4.30 \pm$ & $6.02 \pm$ & $73.83 \pm$ & $1.60 \pm$ & $953.06 \pm$ \\
\hline & 1.12 & 0.39 & 0.23 & 0.20 & 0.24 & 0.41 & 3.16 \\
\hline \multirow[t]{2}{*}{ Sem bean } & $135.81 \pm$ & $251.46 \pm$ & $4.91 \pm$ & $6.02 \pm$ & $61.19 \pm$ & $1.53 \pm$ & $928.79 \pm$ \\
\hline & 2.99 & 0.41 & 0.35 & 0.23 & 0.19 & 0.35 & 0.37 \\
\hline $\mathrm{CD}(\mathrm{P}<0.05)$ & 6.66 & 1.98 & 1.01 & 0.71 & 3.42 & NS & 6.36 \\
\hline
\end{tabular}

Values are mean $\pm \mathrm{SE}$ of three independent determinations 
sem bean vegetable $(8.53 \%)$. The values of total, insoluble and soluble dietary fiber obtained in present investigation are in close agreement with those reported by Rachna (2006) in various products of Moringa oleifera pods.

The data revealed that sem bean vegetable contained the maximum $(135.81 \mathrm{mg} / 100 \mathrm{~g})$ amount of calcium while french bean vegetable contained the minimum $(51.03 \mathrm{mg} / 100 \mathrm{~g})$ amount. Total phosphorus content of vegetable prepared using four types of beans varied from 243.55 to $251.46 \mathrm{mg} / 100 \mathrm{~g}$, the highest being in sem bean vegetable $(251.46 \mathrm{mg} / 100 \mathrm{~g})$ followed by cluster bean vegetable $(248.55 \mathrm{mg} / 100 \mathrm{~g})$, cowpea bean vegetable $(246.37 \mathrm{mg} / 100 \mathrm{~g})$ and french bean vegetable $(243.55 \mathrm{mg} / 100 \mathrm{~g})$. The data presented in Table 3 indicated that vegetable prepared using cluster bean, cowpea bean, french bean and sem bean contained 6.81 . $6.22,4.33$ and $4.91 \mathrm{mg} / 100 \mathrm{~g}$ of iron content, respectively.

Cowpea bean vegetable contained significantly $(\mathrm{P} \leq$ $0.05)$ higher $(101.51 \mathrm{mg} / 100 \mathrm{~g})$ amount of magnesium as compared to cluster bean vegetable (93.61 $\mathrm{mg} / 100 \mathrm{~g})$, french bean vegetable $(73.81 \mathrm{mg} / 100 \mathrm{~g})$ and sem bean vegetable $(61.19 \mathrm{mg} / 100 \mathrm{~g})$. A nonsignificant $(\mathrm{p} \leq 0.05)$ difference was observed in the zinc and manganese content of the beans vegetable. The french bean vegetable had the maximum (953.06 $\mathrm{mg} / 100 \mathrm{~g}$ ) potassium content, followed by cluster bean vegetable (945.84 $\mathrm{mg} / 100 \mathrm{~g})$, sem bean vegetable $(928.79 \mathrm{mg} / 100 \mathrm{~g})$ and cowpea bean vegetable $(919.41$ $\mathrm{mg} / 100)$. Rachna (2006) reported $10.53 \mathrm{mg} / 100 \mathrm{~g}$ iron in pods vegetable prepared using Moringa oleifera. Punia et al. (2008) reported 14.02 to 29.59 and 1.44 to $1.68 \mathrm{mg} / 100 \mathrm{~g}$ of calcium and iron (fresh weight basis), respectively in potato beans vegetable prepared using cluster beans, cowpea beans and french beans. Chaudhary (2011) reported 75.19 to $76.96 \mathrm{mg} / 100 \mathrm{~g}$ of magnesium in snap peas vegetable.

\section{Conclusion}

Green beans are very good source of protein (12.67 per cent to 17.19 per cent), dietary fiber (37.31 per cent to 26.46 per cent) and minerals specially calcium $(51.03 \mathrm{mg} / 100 \mathrm{~g}$ to $135.81 \mathrm{mg} / 100 \mathrm{~g})$, iron $(4.30 \mathrm{mg} / 100 \mathrm{~g}$ to $6.81 \mathrm{mg} / 100 \mathrm{~g})$, zinc $(3.18 \mathrm{mg} / 100 \mathrm{~g}$ to 6.02 $\mathrm{mg} / 100 \mathrm{~g}$ ) and potassium $(919.41 \mathrm{mg} / 100 \mathrm{~g}$ to 953.79 $\mathrm{mg} / 100 \mathrm{~g})$. Cowpea bean vegetable contained highest $(17.19 \%)$ amount of crude protein. The cluster bean vegetable contained maximum amount of total dietary fiber $(37.34 \%)$, insoluble dietary fiber $(24.54 \%)$ and soluble dietary fiber $(12.77 \%)$ whereas sem bean vegetable the minimum amount of total dietary fiber (26.89 $\%$, insoluble dietary fiber $(17.93 \%)$ and soluble dietary fiber $(8.53 \%)$, respectively. The sem bean vegetable contained the highest $(135.81 \mathrm{mg} / 100 \mathrm{~g})$ amount of calcium, phosphorus (251.46 $\mathrm{mg} / 100 \mathrm{~g})$ and zinc
$(6.02 \mathrm{mg} / 100 \mathrm{~g})$. The maximum amount of iron, magnesium and potassium was determined in cluster bean vegetable $(6.81 \mathrm{mg} / 100 \mathrm{~g})$, cowpea bean vegetable $(101.51 \mathrm{mg} / 100)$ and french bean vegetable $(9.53 .79 \mathrm{mg} / 100 \mathrm{~g})$, respectively. During the season, green beans can be used as fresh pods for making various recipes so as to increase the protein, dietary fibre and mineral content of the products. Combination of different green beans should be used so as to gain maximum nutritional benefit.

\section{REFERENCES}

AOAC. (2000). Official Methods of Analysis of Association of Official Agriculture Chemist. Association of Analytical Chemist, Washington. D.C.

Bajpai, P. 2011. Nutritional and sensory evaluation of vegetables grown under organic and inorganic conditions. M. Sc. Thesis, CCS HAU, Hisar, India.

Chaudhary, V. 2011. Nutritional evaluation of snap peas and their utilization for product development. M. Sc. Thesis, CCS HAU, Hisar, India.

Christenhunz, M.J.M. and Byng, J.W. (2016). The number of known plants species in the world and its annual increase. Phytotaxa, Mangolia Press. 261 (3) : 201-217.

Deol, J.K. and Bains, K. (2010). Effect of household cooking on nutritional and anti-nutritional factors in green cowpea (Vigna unguiculata) pods. J. Food Sci. Technol . 47 (5): 579-581.

Furda, I. (1981). Simultaneous analysis of soluble and insoluble dietary fiber. The Analysis of Dietary Fiber in Food. W.P.T. James and O. Theander (Eds). Marcel Dekker, Inc., New York. pp 163-172.

Kala, A. and Prakash, J. (2006). The comparative evaluation of the nutrient composition and sensory attributes of four vegetables cooked by different methods. Intr. J. Food Sci. Technol. 41: 163-171.

Kmiecik, W., Lisiewska, Z. and Jaworska, G. (2000). Contents of ash components in the fresh and preserved broad beans (vicia faba v major). J. Food composition and analysis. $13: 905-914$.

Laparra, J. M., Glahn, R. P. and Miller, D. D. (2009). Assessing potential effect of inulin and probiotic bacteria on Fe availability from common beans (Phaseolus vulgaris L.) to caco-2 cells. J Food Sci. 74 : 40-46.

Lindsey, W.L. and Norwell, M.A. (1969). A new DPTATEA soil tests for zinc and iron. Agron. Abst. 61: 84.

Rani Mamta, Punia, D. and Khetarpaul, N. (2013). Nutrient composition of pulao containing fresh beans. Annals of Agri-Bio Research 18 (2): 293-295.

Punia, D., Gupta, M.,Yadav, S. K. and Khetarpaul, N. (2008). Nutrient composition of green beans and their products. J. Indian Dietetics Association. 33 (1) : 27-32.

Rachna, (2006). Development and nutrient composition of value added products from Drumstick (Moringa oleifera). Ph.D. Thesis, CCS HAU, Hisar, India.

Ranganna, S. (1986). Manual of analysis of fruits and vegetable products. Tata McGraw Hills Publishing Company LTD., New Delhi.

Saxena, K. B., Kumar, R. V. and Gowda, C.L.L. (2010). Vegetable pigeon pea - a review. J. of Food Legumes. 23 (2) : 91-98. 